\title{
A relação entre Mídia e o Medo do Crime: breves considerações
}

Thaís dos Santos Souza?

Resumo: $\bigcirc$ presente artigo discute a complexidade do fenômeno da relação entre a mídia e o medo do crime, tendo em vista que a mídia retrata a criminalidade, notadamente o crime violento, com pouco comprometimento com a função social. Frente a estas notícias e informações relatadas pela mídia, proporciona consequências à segurança pública, tais como o aumento do sentimento de insegurança. Diante disto, o presente estudo tem como objetivo compreender a relação entre a mídia, o medo do crime e suas consequências para a segurança pública.

Palavras-chave: Mídia. Insegurança. Consequências.

\begin{abstract}
This article discusses the complexity of the phenomenon of the relationship between the media and the fear of crime, considering that the media portrays crime, especially violent crime, with little commitment with the social function. Faced with this news and media-reported information, it has consequences for public safety, such as increased feelings of insecurity. In view of this, the present study aims to understand the relationship between the media, the fear of crime and its consequences for public safety.

Keywords: Media. Insegurity. Consequences.
\end{abstract}

\section{Introdução}

Nos últimos anos tem-se assistido a uma grande virada na história da informação. A quantidade de informação que recebemos diariamente cria uma nova forma de medo, mais evasiva e abstrata (AUGE, 2013). A alta exposição dos crimes na mídia e a maneira como são mostrado e opinado sobre os diversos casos criminais, facilmente alimenta uma imagem subjetiva e enviesada do crime, podendo influenciar na sensação de insegurança e comportamento do quotidiano dos indivíduos.

Segundo Bayer (2013) existe uma influência mútua entre o discurso sobre o crime e o imaginário que as pessoas têm dele e entre as notícias e o medo do crime. Diante disto, pode-se sustentar que existe uma relação sólida entre as informações de crime e a sensação de insegurança.

com isso, a finalidade deste trabalho é o de expor breves considerações da ação da mídia frente à criminalidade e suas consequências na segurança pública. Para o desenvolvimento

TÉ Bacharel em Direito pela Universidade de Uberaba - UNIUBE, campus Uberlândia. Licenciada em Letras e Linguística pela Universidade Federal de Uberlândia - UFU. No presente momento está a tirar Mestrado em Criminologia na Faculdade de Direito da Universidade do Porto, Portugal. Possuo Experiência na área de Letras, com ênfase em Língua Portuguesa, Literatura e Linguística. Fu Formadora em Oficinas de Redação em escolas estaduais na cidade de Uberlândia. Além disso, fu professora em Língua Portuguesa, Literatura e Redação, no Brasil. E-mail: thaissouza4@yahoo.com 
deste trabalho foi realizado uma pesquisa de natureza qualitativa, através de uma revisão bibliográfica, tendo como fonte livros, artigos científicos em torno da temática em questão.

Diante deste cenário buscamos compreender a relação da mídia e o sentimento de insegurança, procurando identificar, através dos estudos já realizados na comunidade científica em torno da temática as consequências que as notícias de crime podem ter na sociedade.

\section{Relação Mídia e Sentimento de Insegurança}

A relação entre a mídia e o medo do crime é um tema de fundamental importância para a sociedade contemporânea, tendo em vista a complexidade do fenômeno no processo da construção do crime. A forma como a mídia retrata o ato criminoso, especialmente o crime violento, em sua peculiaridade, proporciona para a segurança pública várias preocupações entre elas o aumento do sentimento de insegurança.

Assistimos diversas produções científicas concernentes à influência da mídia na construção da imagem da criminalidade. Tanto o jornalismo quanto a literatura transformam a criminalidade em um verdadeiro espetáculo com o intuito de atrair a atenção do público, tendo a conduzir gradualmente na sensação de insegurança (GREGÓRIO, 2014, p. 65).

Nesta esteira, compreende-se que o temor da criminalidade possui vários fatores que influenciam em seu crescimento, tais como, a percepção do aumento da criminalidade violenta; experiência pessoal vivida pelo indivíduo ou por pessoas próximas; informações da mídia; mudanças sociais, tais como desemprego, status social, anonimato (CASTRO; FILHO; MONTEIRO, 2011, p. 95).

Mas para compreendermos melhor, no que consiste, de fato, o sentimento de insegurança? Após a uma revisão na literatura sobre o tema, verificamos que o fenômenos da (in) segurança caracteriza-se por uma multiplicidade de componentes (GUEDES, CARDOSO AGRA, 2012, p. 214).

Segundo a comunidade acadêmica, a (in)segurança é construída por três dimensões fundamental, tendo o medo do crime, representando a componente emocional; a percepção do risco do crime, como componente cognitiva, a reação do individuo frente à situação de perigo, como componente comportamental (GUEDES, 2012, p. 1) e segundo a Escola de Criminologia e Justiça Criminal da Flórida há ainda mais duas dimensão para o levantamento e relatos de percepção ao medo do crime, como a percepção da aplicação da lei; e a percepção do jovem acerca do crime e justiça (SANTOS JÚNIOR, DUTRA, SILVA FILHO, 2007, p. 98)

Para a presente revisão, abordamos somente a componente emocional (o Medo do crime - Fear of Crime), isto pelo fato do medo do crime, por exemplo,

[...] não resultar só das experiências de vitimação ou da probabilidade de se poder vir a ser vitimado por um ato delinquente, mas também da dinâmica informativa e mediática transmitida ao vivo e em direto pelas mídias. Esse sentimento, ou a propensão à insegurança na vida moderna, resulta do modo como os poderes públicos e os órgãos de comunicação social gerem tal situação. (LEAL, 2010, p.404)

Sob essa perspectiva, Fattah (1997, p.14) nos chama à atenção que as percepções públicas sobre a vitimação constituem-se normalmente em "fontes secundárias de informações". Entre estas, a mídia, que tem sido apontada como umas das principais fontes de informação 
sobre o crime (apud MACHADO, 2004, p. 106).

A mídia com a veiculação reiterada da violência obtém "um papel determinante na forma como os indivíduos compreende o ato e até mesmo se o mesmo é violento ou não" (MACHADO, 2004, p.110). Para Leal (2010 p.421 a mídia não só desperta "a atenção dos indivíduos sobre determinados temas, em detrimentos de outros, como instrui o indivíduo no método supostamente mais adequado para a leitura dos fenômenos". Na perspectiva do autor, "as condutas e os acontecimentos de natureza criminógena noticiadas de forma continuada pelos órgãos de comunicação social, produzem nos indivíduos um efeito potenciador e catalizador da atenção desses, por que sabem que desse modo é possível estimular a curiosidade das pessoas' (LEAL, 2010, p. 421).

Júnior (2009) entende que

a mídia é uma vasta rede de canais interligados de comunicação, tecnologia e eventos que desempenham um papel relevante na construção social do crime, dado que o público tende a se valer das informações por ela transmitidas para construir uma imagem da criminalidade e para modelar suas atitudes e opiniões com base na percepção dessa mesma imagem (apud GREGÓRIO, 2014, p.66).

De um modo mais concreto, Gregório (2014, p.67) adverte que se nos atentarmos, verificamos que os meios de comunicação não estão interessados em amenizar o problema da criminalidade e sim focalizar-se nos crimes bárbaros.

Para o autor, "uma problemática encontrada na relação entre a mídia e o crime é a realidade invertida da notícia criminal e a forma pela qual os meios de comunicação retratam o crime violento" (GREGÓRIO, 2014, p.66). Para explorarmos esta problemática, buscamos focar na ideia de que os meios de comunicação "funcionam como aliados dos órgãos de controle social, alimentando o medo e a punibilidade" (MACHADO, 2004, p. 112-113).

Bernardes (n.d. apud RODRIGUES (2017, p. 19),) aponta que as notícias de violência e criminalidade, mais do que informar, pretendem emocionar, estimulando o próprio medo e despertando interesse quanto ao assunto. Na perspectiva de Sacco (1995 apud MACHADO, 2004, p.108) tal atração se deve "as características inerentes a este fenômeno que se conforma com as exigências da produção de notícias". Em contrapartida, Machado (2004, p. 108) entende que "o crime, especialmente os que são violentos, possui o valor dramático exigido pela mídia, ou seja, obedece ao conjunto de critérios que determinam a seleção de um tema pelos jornalistas, designados por "valores de noticiabilidade"'.

Com efeito, Carli, Sagant e Capobianco (2008) verificaram que as notícias de crime têm um quadro problemático que auxilia para aumentar o sentimento de insegurança, alimentando a opinião pública e a percepção de políticas públicas (apud RODRIGUES, 2017, p. 19). Por outro lado, Machado (2004, p. 115) assenta que é simples presumir um "efeito direto e universal de indução de medo no público, sendo, no entanto, muito provável que o impacto da mídia seja moderado, pois para a indução do medo no indivíduo, há um conjunto de componentes pretéritas do receptor que interfere no estímulo ao medo (e.g. o sexo feminino, vitimação pretérita, nível prévio de medo)".

Sob outra perspectiva, Gregório (2014, p.69) advoga que ao fazer uso do fato criminoso e da violência sem uma possível perspectiva ética e comprometida com a realidade, os órgãos de comunicação social alimenta o sentimento de insegurança, "o que vem a provocar angústia nas pessoas, passando estes a acreditar que todo mundo é mau, e que as ruas, as praças, 
o bairro e as feiras de mercado são perigosos, causando a síndrome do pânico na população".

O medo induzido pela mídia pode muitas vezes ser intenso e durar longos períodos. Nem sempre é fácil prever qual conteúdo será perturbador. Ao avaliar o provável níve dos danos causados pelo conteúdo assustador, é preciso distinguir os tipos de conteúdo (p. ex., ameaça física ou psicológica), grau de realismo, motivação para "exposição", além de variáveis de receptor relacionadas a personalidade, idade e estabilidade emocional (McQUAIL, 2013, p. 454).

Nesta mesma linha, Rolim (2006, p.191 apud GREGÓRIO, 2014, p. 66) acentua que "a maior parte dos meios de comunicação no Brasil está comprometida com o discurso de que o crime está fora de controle e que a violência cresce de forma assustadora". Ainda, há que se destacar que a mídia possui a capacidade de formar conceitos, entretanto o problema é que algumas informações são veiculadas com pouco compromisso com a função social que se deve ter (BRIGE, 2007 apud GREGÓRIO, 2014, p. 67)

\section{Segurança Pública}

Ante a esta temática de mídia e sua relação face ao sentimento de insegurança, é pertinente tecer alguns considerações sobre a segurança pública, uma vez que uma e outra são realidades indissociáveis

O crime pode conduzir à sociedade um pesado ônus pelo seu impacto na qualidade de vida e na saúde física e mental dos indivíduos. A criminalidade tem contribuído no desvio de recursos essenciais ao desenvolvimento e à riqueza dos países e ao bem-estar dos sujeitos o mesmo tem conduzido àquilo que a sociedade acadêmica chama de fear of crime, cuja associação com a criminalidade leva a um impacto negativo e marcante na democracia.

É interessante notar que o crime não afeta somente as vítimas, mas também os seus familiares, amigos, as testemunhas e indiretamente toda a sociedade condicionando a insegurança e o medo nos sujeitos, mesmo quando o risco de vitimação é baixo. Com efeito, a segurança pública vem sofrendo aquilo que Kahn e Zanetic (2005, p. 64) chamam de "erosão da atuação do governo provocada pelas iniciativas comunitárias de autodefesa".

Os autores apontam que a segurança pública tem deixado progressivamente de ser um tipo de atividade especialmente estatal. Tendo em vista que as causas desta erosão da atuação do governo estatal estão o aumento da criminalidade, do sentimento de insegurança e do reconhecimento de que sozinho, o poder público estatal não consegue atender a todas às necessidades específicas de segurança demandadas pela sociedade.

Ante a isto, observa-se que o medo do crime causa um impacto negativo na qualidade de vida dos indivíduos e das comunidades, podendo, trazer consequências individuais, coletivas, políticas e econômicas significativamente (DANTAS; DE PERSIJN, DA SILVA, 2007, p. 13). Entre elas, o dano psíquico, o abandono e esvaziamento demográfico, a falta de confiança dos cidadãos no Estado e na gestão da segurança pública

A relação entre os profissionais de segurança e os cidadãos não é simples, porque os dois grupos têm uma visão diferente da importância dos delitos. Para o cidadão comum ( a velhinha a quem foi roubada a carteira), a pequena delinquência é um fenómeno grave; para a polícia, o que tem importância de fato são as perturbações da ordem pública ou a criminalidade. "Os policias estão apegados ao carácter repressivo 
do seu trabalho, eles não querem ouvir falar de trabalho social da policia. É contudo isso que a população espera deles" (ROCHÉ, 1994,116).

Nota-se, portanto, que o medo do crime mobiliza a opinião pública, principalmente com a participação da mídia, que passa a pressionar as autoridades responsáveis pela gestão da segurança pública para adotar medidas efetivas de controle da criminalidade (DANTAS; DE PERSIJN, DA SILVA, 2007, p.14).

\section{Conclusão}

Diante deste cenário de medo proporcionado pelos meios de comunicação, a segurança pública passa, com isso, a perder ferramentas essenciais no policiamento estratégico, pois, segundo Gregório (2014, p.69), o pânico faz com que as pessoas se tornem reclusos em suas próprias casas, provocando menor vigilância natural destas pessoas frente aos crimes. E para a segurança pública "a comunidade é um elemento fundamental para o combate a criminalidade, pois as pessoas acionam a polícia e transmitem informações relevantes para o bom atendimento das ocorrências" (GREGÓRIO, 2014, p.69)

Ainda, essa atração da mídia pelo crime nos leva a perceber que a notícia não é apenas mera reprodução de acontecimentos, mas sim fruto de um esforço discursivo sobre o qual existem interesses e objetivos determinados (GOMES, ALBUQUERQUE, 2004).

Diante disto, com a grande exposição do aumento da criminalidade através da mídia acaba por gerar um sentimento de insegurança um pouco irreal e até mesmo imaginário. A atuação da mídia face ao crime está levando o que Silveira (2013) e Glassner (2003) chamam de 'cultura do medo', isto é, o que tem levado os indivíduos a se sentirem mais vulneráveis construindo muros e barreiras, assim como o de se isolarem dentro de suas próprias casas evitando sair em espaços públicos por medo da violência que é na maioria das vezes banalizada pelos meios de comunicação.

Com isso, com as notícias de criminalidade se repetindo frequentemente no quotidiano das pessoas, com o tom dramático, os efeitos e impactos na vida dos indivíduos, bem como na segurança pública, não pode ser ignorado, merecendo reflexões sobre o assunto.

\section{Referências}

AUGÉ, M.. Les Nouvelles peurs. Paris: èditions Payot \& Rivages, 2013.

BARAK, G.. Media, society, and criminology. In. BARAK, Gregg (ed.) Media, process and the social construction of crime: Studies in Newsmaking Criminology. New York: Garland, 1994

BAUMAN, Z.. Medo líquido. Rio de janeiro: Jorge Zahar Editor, 2008.

BAYER, D. A. A Mídia, a reprodução do medo e a influência da política criminal. In. Controvérsias Criminais: Estudos de Direito Penal, Processo Penal e Criminologia. Jaraguá do Sul. Letras e Conceitos. 2013.

DANTAS, G F. L.; DE PERSIJN, A.; DA SILVA JÚNIOR, À. P. O medo do crime. O Alferes, v. 22, n. $62,2007$. 
DE CASTRO, H. H. M.; MATRAK FILHO, R.; MONTEIRO, V. B. O sistema de segurança pública e o medo do crime. Revista Ordem Pública, v. 4, n. 1/2, p. 91-100, 2011.

FORT, M. C. Insegurança e medo: exageros midiáticos? In. Ação Midiática-Estudos em Comunicação, Sociedade e Cultura. Curitiba. PPGCOM-UFPR. ISSN 2238-0701. v. 1, n. 11, p. 73-102, 2016.

GLASSNER, B. Cultura do Medo. São Paulo: Francis, 2003.

GOMES, M.A.M.; AlBuQueRQue, F. D. S. Mídia, Medo e Expansão Punitiva. Porto Alegre: Llivraria do Advogado. 2014.

GREGORIO, J. O. A Relação entre a mídia e o crime: Um estudo bibliográfico sobre a mídia, demonstrando como os noticiários retratam o crime violento e as consequências disso para a Segurança Pública. Ciência \& Desenvolvimento-Revista Eletrônica da FAINOR, v. 7, n. 1, 2014

GUARESCHI, P. A. Mídia E Democracia: O Quarto Versus O Quinto Poder, In. Revista Debates Porto Alegre, v. 1, n. 1, 2007, p. 6-25.

GUEDES, I.; CARDOSO, C.; AGRA, C. Medo do crime: Revisão conceptual e metodológica. C. Agra. In. A criminologia: um arquipélago interdisciplinar. 2012, p. 213-249.

GUEDES, I. Medo do crime: Emergência, reações emocionais e discursos. Contributos para a utilização de multi-metodologias. Tese de doutoramento, Faculdade de Direito da Universidade do Porto, Porto, Portugal. 2016

KAHN, T.; ZANETIC, A. O papel dos municípios na segurança pública. Estudos Criminológicos, v. 4, p. 1-68, 2005 .

LEAL, J.M.P. O sentimento de insegurança na discursividade sobre o crime. Sociologias, Porto Alegre, Vol. XII, n. 23, p. 394-427. 2010.

MACHADO, C., AGRA, C. Insegurança e medo do crime: da ruptura da sociabilidade à reprodução da ordem social. In. Revista Portuguesa de Ciência Criminal, 12(1), 79-101. 2002.

MACHADO, C. Crime e Insegurança. Discursos do medo, imagens do outro. Lisboa: Editorial Notícias. 2004.

McQUAIL, D. Teorias da comunicação de massa. Porto Alegre: Penso, 2013.

PALADINO, C. F. Medo do Crime, mídia e controle Penal: óbices à efetivação do direito fundamental à presunção da inocência no processo penal do espetáculo. Curitiba. Faculdades Integradas do Brasil. Mestrado em Direito, 2010.

ROCHÉ, S. Insécurité et libertés, Paris, Seuil, 1994.

RODRIGUES, A.C.M. O impacto das notícias de crime na sociedade portuguesa. Dissertação 
de Mestrado em Ciências da Comunicação, Faculdade de Letras da Universidade do Porto, Porto, Portugal. 2017.

SÁ, T. V. Segurança e o seu sentimento na cidade. In: Comunicação Apresentada no IV Congresso Português de. 2000.

SANTOS JÚNIOR, A. A.; DUTRA, L. H.; SILVA FILHO, D. B. Levantamento da percepção do medo e do crime em Santa Catarina. Revista Brasileira de Segurança Pública. Ed. 2. 2007.

SILVEIRA, F. L. A cultura do medo e sua contribuição para a proliferação da criminalidade. In: Congresso Internacional De Direito e Contemporaneidade. 2013. p. 295-309.

SINGER, A. Mídia e Democracia. In. Revista USP, São Paulo, n.48, p. 58-67. 2001.

SHECAIRA, S. S. Criminologia. São Paulo: Revista dos Tribunais, 2012.

SURETTE, R. Media, crime, and criminal justice. Wadsworth Cengage Learning: Belmont 2011.

VALENTE, A. C. C. Violência na Imprensa crime violento na imprensa portuguesa: Estudo comparativo de dois jornais diários. Dissertação de Mestrado em Psicologia, Universidade Lusófona de Humanidades e Tecnologias - Faculdade de Psicologia. Lisboa, 2009.

VESTENA, C.I.B. O papel da mídia na formação da opinião pública: a contribuição de Bourdieu. Guairacá - Guarapuava, Paraná, n.24 p.9-22. 2008.

Recebido: 07/05/2018 Aceito: 07/05/2019 